\title{
SERUM LUTEINIZING HORMONE DURING THE PREGNANCY OF A ZEBU COW
}

\author{
W. R. GARR* \\ National Council for Scientific Research, P.O. Box 49, Chilanga, Lusaka, Zambia
}

(Received 3rd May 1971)

For studies on the serum LH concentrations of Zebu cattle during the oestrous cycle (Carr, 1971), sequential blood samples were collected from one pregnant cow. A solid phase radioimmunoassay for LH (Goding, Catt, Brown, Kaltenbach, Cumming \& Mole, 1969) was carried out on the separated sera and several were found to provide elevated values. As levels of blood LH in pregnant sheep are reported to be consistently low (Geschwind \& Dewey, 1968; Niswender, Roche, Foster \& Midgley, 1968; Goding et al., 1969), it was decided to collect regular samples for assay until parturition.

The subject was a 5-year-old Angoni (short-horned Zebu) cow in good condition which had calved 9 months previously. Rectal palpation indicated that the animal was 3 to 4 months pregnant at the time that the first blood samples were collected. Blood samples were collected by venipuncture at least daily until parturition.

All serum samples were compared with NIH-LH-B6 kindly supplied by the Endocrine Study Section of the National Institutes of Health, Bethesda, Maryland, U.S.A., and a general base-line value of $0.5 \mathrm{to} 3 \mathrm{ng} / \mathrm{ml}$ was obtained. This value was similar to that obtained during the oestrous cycle (Schams \& Karg, $1969 \mathrm{a}$; Carr, 1971). However, it was soon apparent that sharp increases in the level of LH secretion occurred for periods lasting 3 days or less and at varying intervals. Many of these peak levels reached a value of 100 to 2000 times the base-line values. These peaks of activity were usually characterized by a very sharp onset, followed by a tailing away over 2 or 3 days. For instance, sequential samples taken at 08.00 hours daily at about Day 180 of the gestation period were as follows: $1 \cdot 0,1 \cdot 2,2000,60,14 \cdot 4,6 \cdot 0,2 \cdot 4,1 \cdot 4 \mathrm{ng} \mathrm{LH} / \mathrm{ml}$. The main peak, however, always dropped to a relatively low value within $24 \mathrm{hr}$.

The sharpness of these peaks was analogous with those obtained during the oestrous cycle (Schams \& Karg, 1969a; Carr, 1971) and emphasized that frequent sampling was necessary to ensure detecting peak values. The half-life of exogenous LH in blood has been reported as about 35 min (Schams \& Karg, $1969 \mathrm{~b})$, and this quick clearance is obviously of great significance particularly during pregnancy.

The first peak detected, showing a maximum value of $200 \mathrm{ng} / \mathrm{ml}$, occurred when the animal was about 4 months pregnant and was observed in two blood samples collected at 08.00 and 16.00 hours on the same day. Sequential samples

* Present address: A. R. G. Animal Breeding Research Organisation, West Mains Road, Edinburgh EH9 3JQ. 
before and after the peak were low. A small peak of $12 \mathrm{ng} / \mathrm{ml}$ was detected 21 days later and, after a further 14 days, considerable fluctuation of values occurred ( 1 to $15 \mathrm{ng} / \mathrm{ml}$ ), persisting for about 10 days and culminating in a sharp peak of $400 \mathrm{ng} / \mathrm{ml}$. Thereafter, an irregular pattern of exceedingly high values separated by between 5 and 10 days occurred, with a final peak of $5500 \mathrm{ng} / \mathrm{ml}$ at 7 months' gestation. This period of intense blood LH activity lasted for 6 weeks.

Recently, Donaldson, Bassett \& Thorburn (1970) have reported on the progesterone concentration in peripheral plasma in cows in different reproductive states. In pregnancy, progesterone rose initially, declined during midpregnancy, and then increased to maximum values. This decline during midpregnancy presumably occurred in the period of intense LH activity reported here.

Evidence exists that LH plays a major rôle in the maintenance of luteal function in the ewe (Nalbandov \& Karsch, 1968), and the same would be expected to apply to the cow. The effect of oestradiol on the preovulatory release of pituitary LH in the ewe was clearly shown by Goding et al. (1969) who suggested that it was a major factor in the mechanism of LH release. Although increases in plasma oestrogen have been shown to occur in the later stages of pregnancy in the cow (Saba, 1964; Pope, Jones \& Waynforth, 1965), these appear to occur later in the gestation period than the LH peaks reported here.

After 7 months, serum LH concentrations dropped to 1 to $4 \mathrm{ng} / \mathrm{ml}$ until within 2 weeks of parturition, when levels were reduced to below the sensitivity of the method $( \pm 0.5 \mathrm{ng} / \mathrm{ml})$ in most samples. This corresponds to the decrease in plasma progesterone (Donaldson et al., 1970) and increase of oestrogen (Saba, 1964; Pope et al., 1965) on calving.

This work was supported by Research Contract Programme No. 799/RB of the International Atomic Energy Agency. I am grateful to Dr R. B. Snook for supplying the antiserum, and to Mr J. Parshotam, Mr A. Nkhoma and Mr G. Mateyo for technical assistance.

\section{REFERENCES}

GARR, W. R. (1971) Radioimmunoassay of luteinizing hormone in the blood of Zebu cattle. F. Reprod. Fert. (In press).

Donaldson, L. E., Bassett, J. M. \& Thorburn, G. D. (1970) Peripheral plasma progesterone concentration of cows during puberty, oestrous cycles, pregnancy and lactation, and the effects of undernutrition or exogenous oxytocin on progesterone concentration. 7. Endocr. 48, 599.

Geschwind, I. I. \& DeWEy, R. (1968) Dynamics of luteinizing hormone (LH) secretion in the cycling ewe: a radioimmunoassay study. Proc. Soc. exp. Biol. Med. 129, 451.

Goding, J. R., Catt, K. J., Brown, J. M., Kaltenbach, C. C., Cumming, I. A. \& Mole, B. J. (1969) Radioimunoassay for ovine luteinizing hormone. Secretion of luteinizing hormone during estrus and following estrogen administration in the sheep. Endocrinology, 85, 133.

Nalbandov, A. V. \& Karsch, F. J. (1968) Proc. Int. Cong. Endocr., 3rd, Mexico City. Ed. C. Gual. Excerpta med. Fdn.

Nrswender, G. D., Roche, J. F., Foster, D. L. \& Midgley, A. R. (1968) Radioimmunoassay of serum levels of luteinizing hormone during the cycle and early pregnancy in ewes. Proc. Soc. exp. Biol. Med. 129, 90 I.

Pope, G. S., Jones, H. E. H. \& Waynforth, H. B. (1965) Oestrogens in the blood of the cow. $\mathcal{F}$. Endocr. 33, 385.

SABA, N. J. (1964) Oestrogenic activity in the plasma of pregnant cows. F. Endocr. 29, 205. 
Schase, D. \& KArg, H. (1969a) Radioimmunologische LH-Beatimmung im Blutserum vom Rind unter Besonderer Berücksichtigung des Brunstzylus. Acta endocr., Copenh. 61, 96.

Sorases, D. \& KARG, H. (1969b) Zeitlicher Verlauf und analytische Erfassbarkeit des endogen bzw. exogen erhöhten Blutspiegels an Luteinisierungahormon beim Rind. Zuchthygiene, 4,61. 